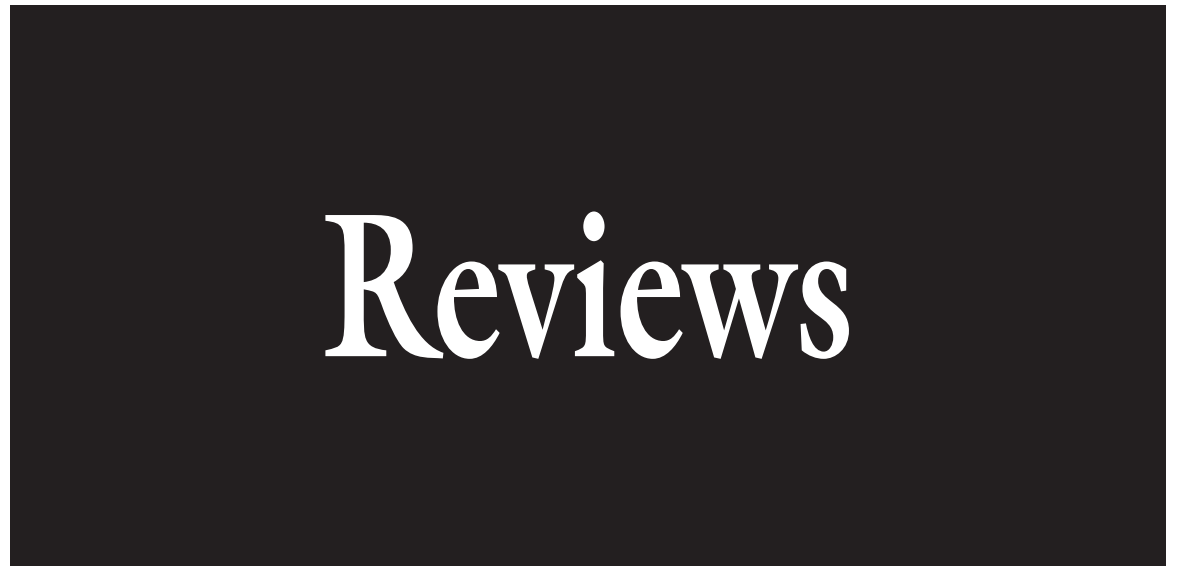

\section{Horseradish Production in Illinois}

\section{S. Alan Walters ${ }^{1,3}$ and Elizabeth A. Wahle ${ }^{2}$}

\begin{abstract}
Additional index words. Armoracia rusticana, Brassicaceae, specialty vegetable crop

SumMARY. Horseradish (Armoracia rusticana) is a hardy perennial that is grown for its white, fleshy, and pungent roots. Illinois leads the United States in production of horseradish, with $\approx 1500$ acres and an annual farm-gate value of about $\$ 10$ million, with most processed and added as an ingredient to various commercially produced condiments. Horseradish in Illinois is primarily grown in the Mississippi River Valley region adjacent to St. Louis due to the well-drained, deep friable, high organic matter, moist loam soils that are present in this area. Most of the production is located in Madison and St. Claire counties. This region of southwestern Illinois has been producing horseradish commercially for over 150 years. This review provides an overview of the basics of horseradish production in Illinois, including propagation, cultivars, planting, cultivation, fertilization, pest management, harvest, grading, storage, and marketing. Horseradish is one of the most important specialty crops grown in Illinois, and current and future production concerns are also discussed.
\end{abstract}

$\mathrm{H}$ orseradish is a hardy perennial that is a member of the Brassicaceae family and is grown for its white, thickened, and pungent roots (Rubatzky and Yamaguchi, 1997). The large primary roots are fleshy with a smooth or corky surface. The intense pungency of horseradish roots is caused by isothiocyanate compounds released from the glucosinolates sinigrin and 2-phenylethylglucosinolate by the naturally occurring enzyme myrosinase found in the plant (Simon et al., 1984). Li and Kushad (2004) found that sinigrin accounted for about $83 \%$ and $91 \%$ of total glucosinolates in horseradish roots and leaves,

${ }^{1}$ Associate Professor, Department of Plant, Soil, and Agricultural Systems, Southern Illinois University, Carbondale, IL 62901

${ }^{2}$ Horticultural Foods Crops Extension Specialist, University of Illinois Extension, Edwardsville Extension Center, Edwardsville, IL 62034

${ }^{3}$ Corresponding author. E-mail: awalters@siu.edu. respectively; and, although horseradish clones differ for total glucosinolate content, little is known about the production of these sulfur-containing glucosides under differing environmental conditions. Furthermore, the horseradish peroxidase enzyme is used extensively in molecular biology, as it is widely used as a reagent for antibody amplification and detection, clinical diagnosis, and other microanalytical immunoassays (Mano and Matsuhashi, 1995).
De Candolle (1959) reported that horseradish most likely originated in the temperate regions of eastern Europe. Horseradish probably had its name derived from the old German word "meerrettich" meaning "sea radish" as the plant grew wild in European coastal areas, and this term was most likely mistaken by English speakers as "mareradish" later becoming horseradish (Courter and Rhodes, 1969; Doll et al., 1999).

Horseradish is well adapted for production in north-temperate sections of the United States [U.S. Department of Agriculture (USDA), 1968], and it often can be found growing wild as it escapes from cultivation in areas having high soil moisture (Magee and Ahles, 1999; Mohlenbrock, 1975). Illinois is the leading producer of horseradish grown in the United States, supplying over $50 \%$ of American demand (Doll et al., 1999; Eastburn and Chang, 1994; Rhodes, 1977; USDA, 2000), with the majority of the horseradish sold to processors for the commercial condiment industry. According to Swiader et al. (1992), horseradish roots and leaves have been used in the past for condiments and medicinal purposes. However, today, only horseradish roots are ground and used in the manufacture of various condiment products for meats and seafood (Rhodes, 1977; Simon et al., 1984; Uchanski et al., 2004). Although the per capita consumption rate of horseradish in the United States was less than $1 \mathrm{oz}$ in the 1970s (Rhodes, 1977), the annual consumption rate has risen slightly since then and is about $1.5 \mathrm{oz}$ based on the amount of product that was processed in 2003 (Kumar, 2003).

\section{Illinois production}

Most of the horseradish production in Illinois can be found in the Mississippi River Valley region adjacent to St. Louis and is located

\begin{tabular}{llll}
\hline $\begin{array}{l}\text { Units } \\
\begin{array}{l}\text { To convert U.S. to SI, } \\
\text { multiply by }\end{array}\end{array}$ & U.S. unit & SI unit & $\begin{array}{l}\text { To convert SI to U.S., } \\
\text { multiply by }\end{array}$ \\
\hline 0.4047 & acre(s) & $\mathrm{ha}$ & 2.4711 \\
0.3048 & $\mathrm{ft}$ & $\mathrm{m}$ & 3.2808 \\
2.54 & inch $(\mathrm{es})$ & $\mathrm{cm}$ & 0.3937 \\
0.4536 & $\mathrm{~b}$ & $\mathrm{~kg}$ & 2.2046 \\
1.1209 & $\mathrm{lb} / \mathrm{acre}$ & $\mathrm{kg} \cdot \mathrm{ha}^{-1}$ & 0.8922 \\
28.3495 & $\mathrm{oz}$ & $\mathrm{g}$ & 0.0353 \\
2.2417 & ton/acre & $\mathrm{Mg}^{\circ} \cdot \mathrm{ha}^{-1}$ & 0.4461 \\
$\left({ }^{\circ} \mathrm{F}-32\right) \div 1.8$ & $\mathrm{o} F$ & ${ }^{\circ} \mathrm{C}$ & $\left(1.8 \times{ }^{\circ} \mathrm{C}\right)+32$ \\
& & &
\end{tabular}


primarily in Madison and St. Claire counties (Doll et al., 1999). This area in southwestern Illinois, which is known as the "American bottoms," is the most concentrated area of horseradish production in the world and has been producing horseradish commercially since the 1890s (Courter and Rhodes, 1969). About 1500 acres of horseradish is produced in this region annually, with an approximate farm gate value of about \$10 million. Generally, about 4 tons of marketable roots are produced per acre (Shehata et al., 2009), with growers receiving about $\$ 1.50 / \mathrm{lb}$, depending upon the root grade. The primary reasons for production in this area are related to site conditions (deep loamy soils conducive to root growth and digging) as well as German immigrant settlement patterns (Bratsch, 2006). Two other major horseradish production areas in the United States are Eau Claire, WI, and Tule Lake, CA (Rhodes, 1977), with smaller acreages in New Jersey and Oregon (C.C. Doll, personal communication; Shehata et al., 2009).

\section{Field production systems}

Horseradish can be produced in an annual or perennial production system. In Illinois, horseradish is grown in an annual production system (Rhodes, 1977), which is similar to that used in Wisconsin (Boerboom et al., 2007) and other eastern states. In an annual production system (Fig. 1), horseradish requires a long growing season with high temperatures during the summer and cooler temperatures in the late summer and fall to enhance root development (Swiader et al., 1992). A large marketable root, also referred to as the primary root,

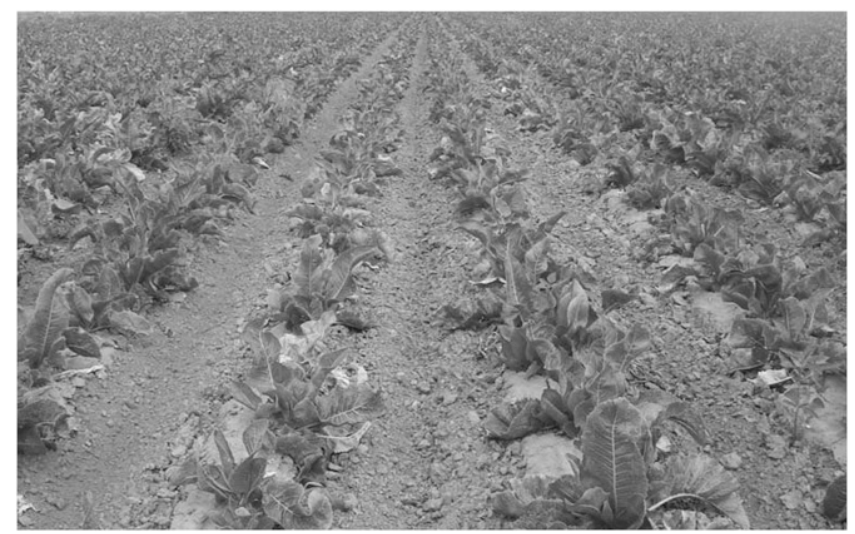

Fig. 1. Horseradish production field during late-spring in Collinsville, IL. develops from a planted secondary root that increases in diameter over the growing season (Rhodes, 1977). During a single growing season in Illinois, horseradish plants will develop a large marketable root mass of varying lengths and diameters. Horseradish is usually planted in the early spring, with most planted by 1 May, and the roots are harvested beginning in early November and ending when the soil freezes (usually mid- to late December). Harvesting usually continues once the soil thaws in late winter to early spring, as quality is not reduced by later harvests. Horseradish is typically placed in a 3- to 4-year rotation with corn (Zea mays) and soybean (Glycine max) (Rundle et al., 2007).

Horseradish produced in a perennial system may stay productive for 10 to 20 years or more. However, the production of horseradish in a perennial system is generally more laborious and requires greater field management compared with an annual production system. In the perennial system, upright, thickened, underground shoots arising from a deeply planted "mother" root are harvested every other year, with the original "mother" plant left in the field for regeneration of new plant material to harvest in future years (Bratsch, 2006). This type of system can still be found in some areas that have a relatively short growing season, such as the Tule Lake region of California and in many parts of Europe.

\section{Horseradish types and cultivars}

Horseradish production in Illinois has traditionally (before the 1980s) included several important types (I, II, or III) that differed based on leaf shape, size, and texture (Bratsch, 2006; Rhodes, 1977; Rhodes et al., 1965a, 1965b). 'Bohemian' and 'Big Top Western' (or Type I) produce upright lamina that tapers toward the attachment point to the leaf petiole $\left(<60^{\circ}\right)$ (Rhodes et al., 1965a). However, 'Bohemian' produces smooth leaves with a lanceolate to oblanceolate shape, while 'Big Top Western' has large, smooth, ovate- to obovateshaped leaves. 'Bohemian' normally produces smooth, high-quality roots, although they are not as large as the 'Common' type that will be discussed next, whereas, 'Big Top Western' produces large, high-quality roots that often have a rough or bark-like exterior. 'Common' (or Type III) has large, crinkled leaves with a $>90^{\circ}$ lamina attachment to the petiole. Although the 'Common' type is known for its high-quality and large roots, it is highly susceptible to turnip mosaic virus (TuMV) and white rust (Albugo candida). Horseradish cultivars of Type I generally have resistance to TuMV and white rust, while those of Type III are susceptible to these pathogens (Rhodes et al., 1965a). Plants of Type II are somewhat intermediate between the other two types, with lamina having more of a rounded $\left(60^{\circ}\right.$ to $\left.90^{\circ}\right)$ attachment angle to the petiole, susceptibility to TuMV, and intermediate resistance to white rust. Because these different types have been used for new horseradish cultivar development in Illinois, the specific leaf characteristics for each type are now difficult to distinguish due to crossbreeding between the various types.

Currently, there are many cultivars that growers use for planting each year, with new material released each year from the Horseradish Growers of Illinois breeding program. Certain cultivars are preferred by specific growers, although most will typically grow four to five or more cultivars. Horseradish growers try to limit the number of cultivars that are grown due to problems associated with preserving the genetic purity of a particular clone when several different ones are grown. Currently, the most widely grown cultivars include: $15 \mathrm{~K}, 22 \mathrm{C}, 1038,1573$, $1590,1722,7586$, D25-E2, and D18El (Table 1; Dorris et al., 2007, 2008). About 10 to 15 years ago, the most widely grown cultivars were 1590, 1573, 1005, 647, 1038, 1069, 
1473, 1722, 1635, and Eastern (A.D. Bratsch, unpublished data).

\section{Horseradish planting}

Horseradish is asexually propagated by planting root sections (referred to as "sets") collected from the previous year's crop (Shehata et al., 2009; USDA, 2000). All Illinois horseradish growers maintain their own set stock from year to year. These sets are typically smaller side roots taken off the main root and range in size from 0.5 to 0.8 inch diameter and 10 to 16 inches long (Rhodes, 1977). Horseradish roots exhibit distinct polarity with a proximal end (or point of attachment to the main root that sprouts producing new vegetation) and distal end. Because the diameter of set roots only slightly narrows from the proximal to distal ends, the grower must keep track of this orientation for planting purposes (Bratsch, 2006; Oregon State University, 2002; USDA, 1968). Therefore, squared-off cuts are often made at the thickened end (proximal end), while tapered cuts are made at the distal end to indicate the polarity of the root. Planting sets are packed into wooden storage bins that

Table 1. Most widely grown horseradish clones in Illinois during 2006 and 2007 (from Dorris et al., 2007, 2008).

\begin{tabular}{lcc}
\hline \multicolumn{3}{c}{ Growers using clone (\%) } \\
\hline Clone & $\mathbf{2 0 0 6}$ & $\mathbf{2 0 0 7}$ \\
\hline 1590 & 100 & 71 \\
$15 \mathrm{~K}$ & 88 & 71 \\
1573 & 88 & 57 \\
7586 & 88 & 57 \\
D25-E2 & 75 & 43 \\
1038 & 50 & 43 \\
$22 \mathrm{C}$ & 50 & 57 \\
3038 & 50 & 43 \\
9705 & 50 & 57 \\
Doll & 50 & 43 \\
9553 & 38 & 29 \\
D18-E6 & 38 & 14 \\
D18-E1 & 13 & 29 \\
9769 & 13 & 29 \\
647 & 13 & 57 \\
V7E3 & 13 & 29 \\
1722 & 13 & 43 \\
German & 13 & 43 \\
Big Top Western & 13 & 14 \\
788 & - & 14 \\
27-4 & - & 14 \\
$28-8$ & - & 14 \\
\hline
\end{tabular}

are lined with heavy plastic liners, with the plastic loosely pulled and sealed over the set roots. These bins are placed in cold storage at about $40{ }^{\circ} \mathrm{F}$ until spring planting (Fig. 2).

In the annual planting system, horseradish planting is done in rows with sets spaced $3 \mathrm{ft}$ apart using 1.3 to $2 \mathrm{ft}$ in-row spacings. About 10,000 sets are required to plant an acre. Row and set spacings are marked once the field is deeply plowed and disced. Sets are generally placed by hand into these marked "pockets" that are made by using a tractor with an attached paddlewheel implement, which creates a "pillowed" or "dished" indentation in the soil (Bratsch, 2006). Sets are laid on the soil at about a $45^{\circ}$ angle (Shehata et al., 2009), with the proximal-end slightly higher as this part is placed on the "pillow" (Fig. 3). Sets are normally oriented in the same direction for several rows (usually four), depending on the cultivation equipment used; this is done to prevent approaching the planted sets' proximal-ends first with cultivation equipment, as this can result in the proximal-end being lifted out of the soil. Once sets are laid out, a dischiller is used to form 1.5 to $2 \mathrm{ft}$ wide ridges that cover them to a depth of 5 to 8 inches (Bratsch, 2006).

\section{Soils, fertilization, and cultivation}

Horseradish grows best on a rich, well-drained, deep friable, moist loam soil with high organic matter content like those found along the Mississippi River Bottoms area of Illinois (Swiader et al., 1992). Horseradish that is grown on soils with shallow, hard subsoils will often produce low biomass roots of poor quality that are highly branched with few useable sets. Horseradish will grow on a wide soil $\mathrm{pH}$ range $(5.5-6.8)$. The advantages of lighter textured soils becomes readily noticeable at harvest, as lighter soils dry faster, often

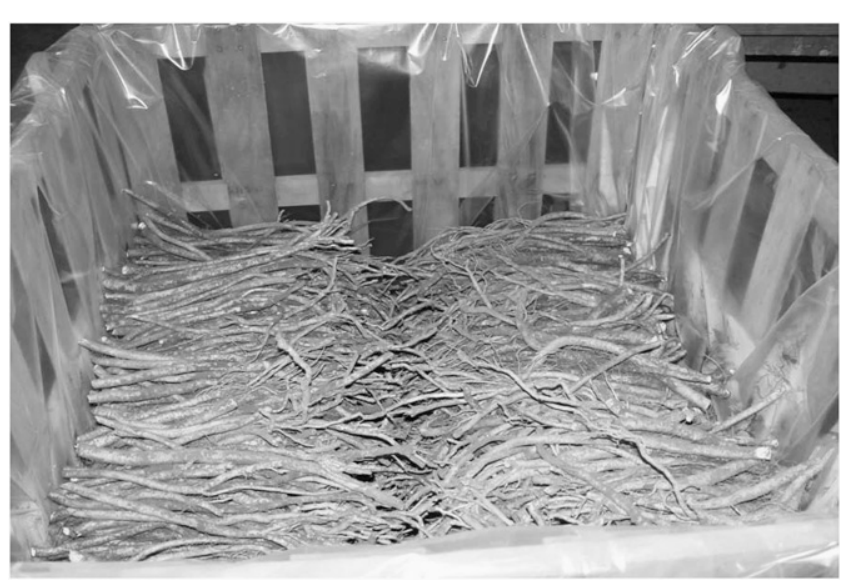

Fig. 2. Horseradish planting sets in plastic-lined palletized bins ready for cold storage or field planting.

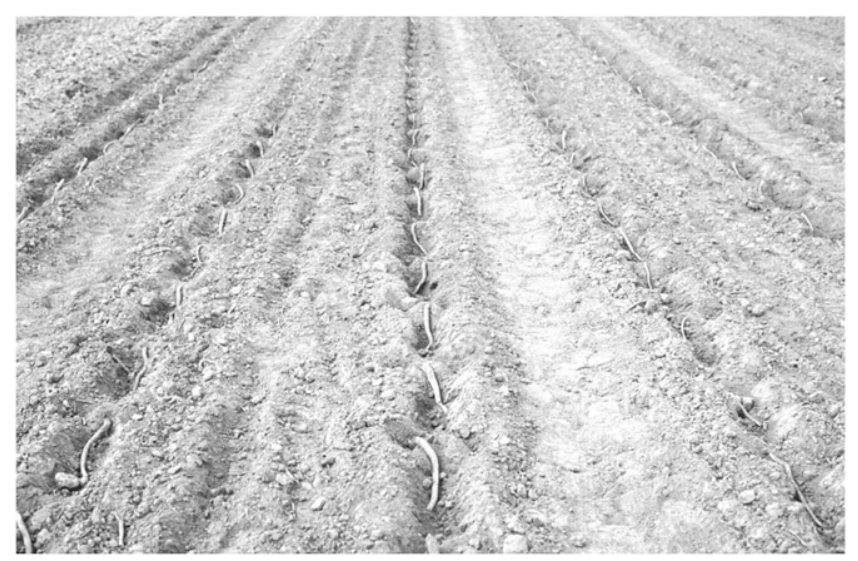

Fig. 3. Horseradish root sets placed in field before covering with soil. 
allowing field digging during the wet conditions of fall, winter, and spring, and lighter soils also adhere less to the root mass compared with heavier soils (Bratsch, 2006).

Horseradish will remove large amounts of nutrients from the soil because it is a relatively long-season crop (Shehata et al., 2009; Swiader et al., 1992). A typical fertilization program includes about $150 \mathrm{lb} /$ acre nitrogen $(\mathrm{N})$, with phosphorus $(\mathrm{P})$ and potassium $(\mathrm{K})$ rates based on soil type or soil test results, with applications generally ranging from 50 to 250 $\mathrm{lb} /$ acre (Gerber and Swiader, 1985). In addition, about 1 to $2.5 \mathrm{lb} /$ acre boron and 15 to $25 \mathrm{lb} /$ acre sulfur is made with the initial $\mathrm{N}-\mathrm{P}-\mathrm{K}$ broadcast application. A sidedress application of 50 to $75 \mathrm{lb} /$ acre $\mathrm{N}$ can be made 8 to 12 weeks after planting, but many growers do not apply fertilizer at this time, as overapplication of nitrogen can promote excessive foliar growth at the expense of root growth, which can lead to the development of hollow or highly branched, irregularly shaped roots (Swiader et al., 1992).

To obtain the largest, straightest marketable roots (Fancy and U.S. no. 1 grades) with low numbers of shoots from the crown (proximal-end), some growers practice "lifting" and "stripping," as this allows optimal sizing and development of the planted set. Typically, this procedure is done twice during the season, when leaves are 6 to 10 inches tall and again about 6 weeks later. Lifting and stripping involves elevating the crown end of the main root out of the soil, stripping off the side roots and most of the crown leaves, and then placing the root back and covering with soil (Swiader et al., 1992). During lifting, the crown portion of the root is slightly lifted a few inches (Rhodes, 1977). This is normally done by gently grabbing and pulling the leaves by hand; however, a U-shape metal rod can also be used to accomplish the task of lifting (Bratsch, 2006). This rod is inserted into the soil with the hook placed beneath the crown of the growing set and lifted. This process removes the early roots forming below the crown and forces more root development at the distal-end, resulting in a larger marketable root. If secondary crown roots are allowed to develop, enlargement of the planted set root is reduced, resulting in fewer high-quality marketable roots (Rhodes, 1977). Also, at the time of lifting, the multiple shoots developing at the crown of the horseradish plant are stripped by hand to leave only one or two shoots. Stripping provides a smoother external surface to the root, which is an important marketable characteristic. The practice of lifting and stripping is an expensive, labor-intensive procedure (Swiader et al., 1992). Horseradish growers that produce the "wild root" grade do not go through the process of lifting or stripping because sets are allowed to grow without any manipulation, resulting in smaller roots (Fig. 4) (Bratsch, 2006). Although over $60 \%$ of growers used the lifting and stripping technique about 10 to 15 years ago (A.D. Bratsch, unpublished data), only a few use this method today. This technique is done only if the grower is selling to a market that desires highquality no. 1 roots (Fig. 5) and if sufficient labor is available.

\section{Irrigation}

Most Illinois horseradish growers do not irrigate. However, irrigation during drought conditions, especially during the late summer into fall, is sometimes done to improve marketable yields because most rootsizing occurs during this period (Shehata et al., 2009).

\section{Weed control}

Growers consider weeds as one of the most important and difficult to control pests in horseradish production (Table 2; Walters, 2009). Horseradish growers use applications of pre- and postemergence herbicides and mechanical cultivation for weed control. Most growers use a tank mix of sulfentrazone (Spartan DF; FMC, Philadelphia) and oxyfluorfen (Goal; Rohm and Haas, Philadelphia) at recommended rates before horseradish emergence (Wahle and Masiunas, 2004). No mechanical cultivation is used until about late June or July so that the herbicide barrier is not broken. Other herbicides, such as S-metolachlor (Dual II; Syngenta Crop Protection, Greensboro, NC), carfentrazone-ethyl (Aim; FMC), dimethenamid-P (Outlook; BASF, Research Triangle Park, NC), sethoxydim (Poast; BASF), and clethodim (Select; Valent, Walnut Creek, CA) are often used as well, depending upon the weeds that need to be managed. Growers that use the lifting and stripping cultivation method will do so only after the

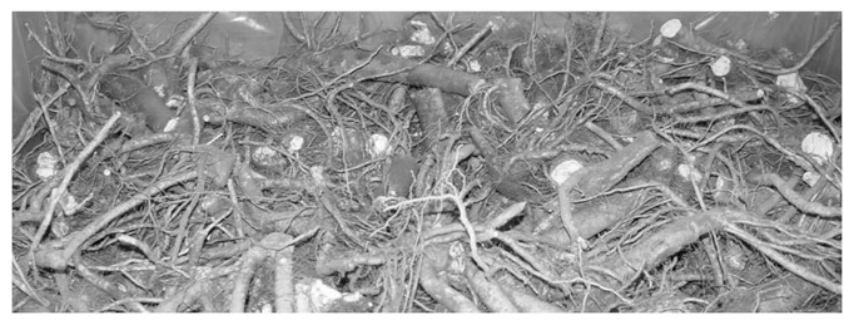

Fig. 4. Wild root grade of horseradish.

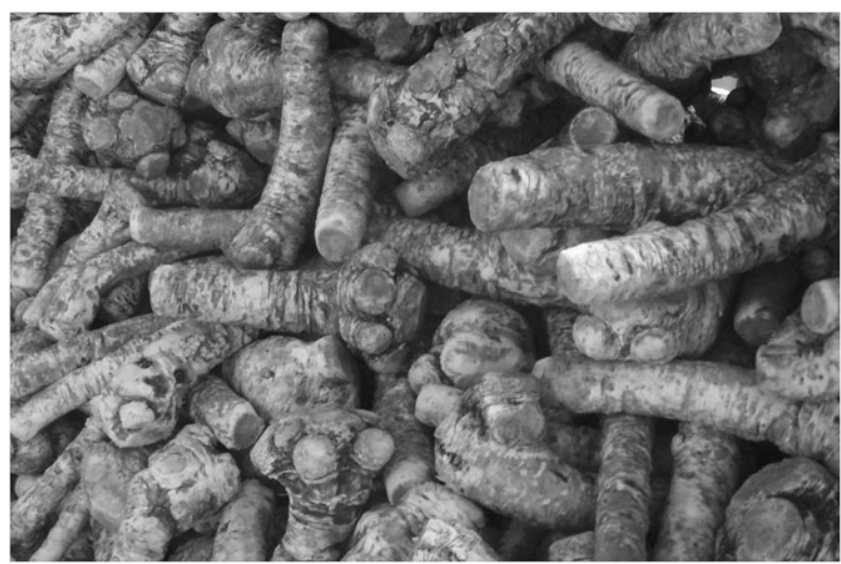

Fig. 5. U.S. no. 1 grade roots of horseradish that are cut and trimmed for the market. 
herbicide effectiveness period has passed. Due to the short herbicide mechanical weed control is generally required and this is achieved by cultivation and/or hand weeding (USDA, 2000).

Because horseradish is a perennial crop, viable roots remain in the soil after harvest and can develop into volunteer plants in subsequent rotational crops (Fig. 6) (Burke and Hopen, 1983; Rundle et al., 2007). Although volunteer horseradish is not extremely competitive with corn or soybean, the occurrence of these plants negates the benefit of crop residuals and the long growing season,

rotation (Bratsch, 2006); a 3- to 4 year crop rotational scheme without volunteer horseradish is important for reducing internal root discoloration [IRD (covered in the disease section)] in subsequent horseradish crops (Johanning et al., 2008a). Volunteer horseradish is difficult to control due to nonuniform emergence because plants emerge from various-sized root pieces that are at different soil depths (Rundle et al., 2007). Burke and Hopen (1983) indicated that volunteer horseradish could be controlled by disking in mid-July followed by an application of glyphosate (Roundup; Monsanto, St. Louis) at $4 \mathrm{lb} /$ acre a.i.

Table 2. Most problematic pests in horseradish production as determined by Illinois horseradish growers (from Walters, 2009).

\begin{tabular}{lc}
\hline Pest & $\begin{array}{c}\text { Ranking } \\
(\mathbf{1}-\mathbf{1 0} \text { scale })^{\mathbf{z}}\end{array}$ \\
\hline Brittle root (Spiroplasma citri) & 2.3 \\
Internal root discoloration disease complex ${ }^{\mathrm{y}}$ & 2.5 \\
Weeds & 2.5 \\
Beet leafhopper (Circulifer tenellus) & 3.1 \\
Volunteer horseradish & 5.6 \\
Foliar leafspots caused by fungal/bacterial pathogens & 6.1 \\
Diamondback moth (Plutella xylostella), false chinch bug & 6.7 \\
$\quad$ (Nysius raphanus or N. niger) and various other foliage & \\
$\quad$ feeding insectsw & 8.0 \\
Turnip mosaic virus & 8.3 \\
Root-knot nematode (Meloidogyne incognita) & 9.2 \\
White rust (Albugo candida) & \\
\hline
\end{tabular}

${ }^{z}$ Ranked from most important to least important as determined by Illinois horseradish growers. Ranking of the 10 pests based on the summation of grower evaluations from the most important $=1$ to the least important $=10$, with 1 to $3=$ high, 4 to $6=$ moderate, and 7 to $10=$ low priority pests. Fifteen growers participated in the survey at the Horseradish Growers School in Collinsville, IL on 31 Jan. 2008 (Walters, 2009).

y'Internal root discoloration is caused by various Fusarium species, Verticillium dabliae, and V. longisporum.

${ }^{x}$ Foliar leafspots include those caused by Alternaria brassicae and Cercospora brassicicola; and bacterial leafspot caused by Xanthomonas campestris pv. armoraciae.

"Other common insect defoliators that rarely cause substantial damage to horseradish include cabbage looper (Trichoplusia ni), imported cabbageworm (Pieris rapae), horseradish flea beetle (Phylletreta armoraciae) and other flea beetles (Coleoptera: Chrysomelidae), grasshoppers (Orthoptera: Acrididae), japanese beetle (Popillia japonica), and onion thrips (Thrips tabaci).

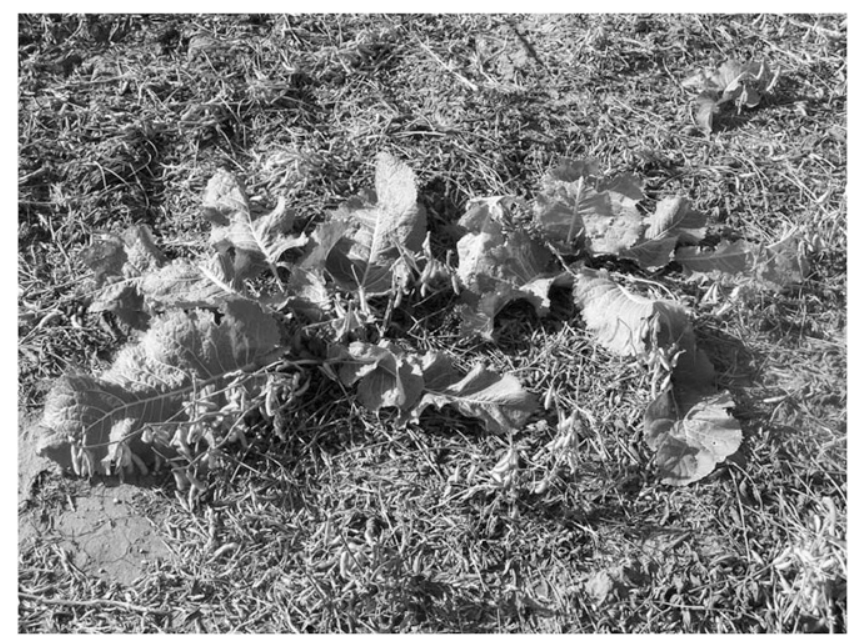

Fig. 6. Volunteer horseradish plant in harvested soybean field. in mid-September. Although glyphosate is typically used by most growers before crop planting or as a postemergence application in glyphosate-resistant corn and soybean, this strategy is not totally effective in controlling volunteer horseradish. Certain postemergence herbicides, such as 2,4-D in corn production, will provide better in-season control of volunteer horseradish compared with glyphosate (Rundle et al., 2007). Johanning et al. (2008b) indicated that late fall applications following soybean harvest can be effective for volunteer horseradish control, with 2,4-D and halosulfuron providing the greatest reduction in plant density.

\section{Insect and disease control}

Most of the information on insect and disease control is adapted from Eastburn and Weinzierl (1995). This publication contains images of the most important diseases and insects of horseradish in Illinois, as well as detailed methods for field scouting.

InSECT CONTROL. There are only a few insect pests that have economic importance in horseradish (Shehata et al., 2009). The primary insect pest of horseradish in Illinois is the beet leafhopper (Circulifer tenellus) (Table 2; Walters, 2009) due to its role in transmitting the brittle root disease (Fletcher et al., 1981; Raju et al., 1981; USDA, 2000), which is caused by the pathogen Spiroplasma citri. These insects do not overwinter in Illinois, but in certain years, large populations will migrate from southwestern states to Illinois, depending on weather patterns. Drought conditions and strong southwesterly wind patterns favor beet leafhopper migration and brittle root disease outbreaks. The brittle root disease tends to be the most severe when migrations occur soon after horseradish plants emerge in May or June. Incidence of this disease was detected in about $10 \%$ and $1 \%$ of Illinois horseradish fields in Sept. 2000 and 2002, respectively (Babadoost, 2003; Babadoost et al., 2001), indicating that growing seasons differ for brittle root incidence depending on beet leafhopper populations. All horseradish growers participate in a weekly scouting program for detection of this insect pest, and insecticide applications are advised if sweep net samples indicate 
the presence of beet leafhoppers before late July or August (Eastburn and Weinzierl, 1995).

The diamondback moth (Plutella xylostella) and false chinch bug (Nysius raphanus or $N$. niger) are important foliage feeders of horseradish, but rarely are found at population densities requiring insecticide treatment. Horseradish is probably the most susceptible to damage from false chinch bugs when high populations develop during drought conditions. Aphids (Homoptera: Aphididae) are important insects due to their role in transmission of TuMV; however, most growers do not associate any reduction in yield or quality due to this disease, thus these insects are often tolerated. Other common insect defoliators of horseradish that rarely cause substantial damage include cabbage looper (Trichoplusia ni), imported cabbageworm (Pieris rapae), horseradish flea beetle (Phylletreta armoraciae), flea beetle (Coleoptera: Chrysomelidae), grasshoppers (Orthoptera: Acrididae), japanese beetle (Popillia japonica), and onion thrips (Thrips tabaci). Fairly large amounts of foliar damage can be tolerated by these insects before substantial root reduction occurs. Flea beetle infestations are not usually found at population densities requiring insecticide treatment; however, new horseradish plants emerging from the soil can be heavily damaged by flea beetles and insecticide applications are advised under these conditions. The imported crucifer weevil (Baris lepidii) is also an important pest of horseradish as it directly feeds on roots and can severely reduce marketable yields; however, it is rarely found above economically damaging population densities. Permethrin (Pounce; FMC) is the insecticide of choice for insect control by many horseradish growers as it has efficacy on most of the problematic insects of horseradish.

Disease control. Horseradish is susceptible to several foliar and root diseases that commonly occur in Illinois. Important foliar diseases include leafspots caused by Alternaria brassicae and Cercospora armoraciae, bacterial leafspot incited by Xanthomonas campestris pv. armoraciae, white rust, and TuMV. Many of these foliar diseases can often be found together on single plants resulting in substantial amounts of leaf blight (Babadoost, 2003; Babadoost et al., 2001).

Alternaria and cercospora leafspots are two or the most common foliar diseases of horseradish in Illinois and are difficult to accurately identify from each other under field conditions (Babadoost et al., 2001). Bacterial leafspot can be a destructive disease especially during wet growing seasons, with entire leaves often curling and becoming dry. Because the pathogens that cause these leafspots overwinter in infested crop residues, crop rotation or incorporation of crop debris is used to reduce future outbreaks.

The most common pathogen of horseradish in Illinois is probably TuMV, and is readily transmitted by several species of aphids (Horwitz et al., 1985). This pathogen was detected in $\approx 16 \%$ and $12 \%$ of Illinois horseradish fields sampled in 2000 and 2002, respectively (Babadoost, 2003; Babadoost et al., 2001). This pathogen is also a significant pest of horseradish in Europe (Górecka and Lehmann, 2001). Characteristic TuMV symptoms on horseradish include ringspots and chlorotic mottling (mosaic) of leaves, black streaks on leaf petioles, and clearing of the leaf veins. Because horseradish is asexually propagated, the virus load in a particular clone can increase with each succeeding growing season, which can further weaken the clone (Uchanski et al., 2004). Although virus-free horseradish plants can be generated by tissue culture, many plants become infected with TuMV during the first season in the field. Most growers do not consider this pathogen to be a significant threat to horseradish production (Table 2; Walters, 2009).

White rust can be an extremely damaging disease of horseradish, as extensive leaf destruction prevents normal root growth and results in significant root yield loss (Eastburn and Weinzierl, 1995). Although white rust is an important disease in many European countries (A. Achleitner, personal communication), it is considered a minor disease of horseradish in Illinois (Table 2; Walters, 2009). This disease can be readily identified by the characteristic white pustules or sori that appear on the lower leaf surface. Albugo candida can become systemic in the crown portion of the plant and will occasionally infect the root. Fall infestations cause more economic damage because this pathogen has the ability to suppress the vigorous root enlargement that occurs during this time of the year. Albugo candida survives in living, infected plant tissues and can be introduced into a field by planting infected root stock or by infected volunteer plants growing in adjacent fields or nearby diseased horseradish fields. Management strategies include crop rotation, the use of disease-free planting stock, and the destruction of volunteer plants in rotational crops. Set roots taken from the crown area of the root are more likely to contain this pathogen because it often infects this portion of the root (Eastburn and Weinzierl, 1995).

Root diseases typically cause greater problems for horseradish growers than foliar diseases. Root diseases will directly affect marketability because little interior root discoloration is tolerated by processors. Widespread root diseases in Illinois horseradish include brittle root (Babadoost, 2003; Babadoost et al., 2001) and IRD disease complex caused by various Fusarium species, Verticillium dabliae, and V. longisporum (Babadoost et al., 2004). Currently, IRD and brittle root are the most important disease problems in Illinois horseradish production (Table 2; Walters, 2009).

Before 1980, brittle root was a devastating disease of horseradish in Illinois, with $30 \%$ to $80 \%$ losses occurring during the epidemic years of 1936, 1953, 1954, 1975 (Rhodes, 1977), and 1979 (Fletcher et al., 1981). The symptoms of brittle root include an inward curling and yellowing of leaves, stunting of new growth, and an eventual collapse of the foliar portion of the plant. The root vascular tissues become discolored and eventually turn from tan to brown or black. Starch accumulates in the roots, which in turn become turgid and snap easily when bent (Rhodes, 1977). The pathogen, S. citri, is transmitted by the beet leafhopper (Fletcher et al., 1981; Raju et al., 1981) and belongs to a group of specialized bacteria called spiroplasmas that are restricted to phloem tissues. This pathogen causes reductions in root quality and yield, and infected roots are smaller than normal, develop a brittle texture, and infected plants die within a few weeks 
after the onset of symptoms. However, as previously described under the section "Insect control," all Illinois horseradish growers today participate in a beet leafhopper scouting program that has prevented significant widespread outbreaks of brittle root during the last 30 years.

In Illinois, as well as other horseradish-growing areas in North America and Europe, internal discoloration of horseradish roots has caused up to $100 \%$ yield losses (C.C. Doll, personal communication). Pathogens that cause IRD do not generally reduce overall yield, but will suppress marketable yield due to the blackening of roots (Chang and Eastburn, 1994). The discoloration often appears as streaks in the vascular tissue when the root is sectioned lengthwise or as black specks when the root is cross-sectioned. Verticillium overwinters in the soil as microsclerotia, which can survive for many years and then germinate in the presence of host plant roots when environmental conditions are favorable (Olsen and Young, 1998). Plants in the Brassicaceae and some in the Solanaceae families are susceptible hosts of $V$. dabliae (Chang and Eastburn, 1994). Crop rotation to nonsusceptible hosts, such as corn and soybeans, is used by growers to reduce soil inoculum levels. However, previous attempts to control this disease by reducing inoculum densities of $V$. dabliae through crop rotation were not successful due to the pathogen's large host range and its ability to survive for long periods of time in the absence of susceptible hosts (Khan et al., 2000). Furthermore, other methods, such as soil fumigation or solarization, have been ineffective or are not economically feasible (Kindhart et al., 2003; Mueller et al., 1982), while heat or fungicide treatment of planting stock has provided mixed results (Babadoost and Islam, 2004; Babadoost et al., 2007).

In attempts to combat this disease, 1) new fields are being planted out of the traditional Illinois Mississippi bottoms area; 2) tissue culture is being used to develop clean planting stock; 3 ) better methods for volunteer horseradish control are being developed; 4) horseradish sets are being treated with heat or various biological and chemical treatments before planting; and 5) the horseradish growers of Illinois fund an active breeding program for IRD resistance. Horseradish germplasm materials identified as resistant to $V$. dabliae, including those identified by Atibalentja and Eastburn (1998), as well as newer resistant materials obtained from Europe, are currently being used to improve IRD resistance in Illinois horseradish clones.

\section{Harvest, grading, storage, and marketing}

Typically, horseradish harvest in Illinois starts once the foliage has been killed by frost (late OctoberNovember) and is continued through the winter and early spring months as long as the soil is not frozen and is dry enough to dig roots (Swiader et al., 1992). To facilitate the harvest procedure, foliage that has not been killed by frost and/or freeze events is generally mowed several days before digging. Harvest operations are normally performed using a one- or two-row commercial potato harvester that has been modified to dig deeper (about $1.5 \mathrm{ft}$ ) into the soil profile (Fig. 7). Although roots can penetrate to depths of $2 \mathrm{ft}$ or greater (Berrie, 1977; Weaver and Bruner, 1927), most of the primary and lateral roots are recovered from the typical digging depths of $<1.5 \mathrm{ft}$; and, harvesting most roots from the soil is critical to reduce the number of volunteer plants that develop in following years. Lateral roots (or sets) must also be recovered and saved for spring planting (Rhodes, 1977). The roots are lifted out of the soil and loose soil is removed from the root system as it travels through the shaking motion of the digger chain and conveyor system. A flatbed wagon catches the roots as they drop off the conveyor or they fall to the ground and are later loaded by hand onto a flatbed wagon (Bratsch, 2006).

After harvest, the roots are brought into a shed where they are trimmed and sorted. For commercial processing markets, roots are generally not washed, but soil adhering to roots is removed in some manner (by hand or revolving tumblers) before shipping. For top grade roots, foliar material remaining on the crown is removed by hand with a knife, as well as any small roots that are attached to the primary root. Those trimmed roots that are large enough for planting sets are placed in heavy plasticlined bins for storage (Fig. 2).

The horseradish crop in Illinois is generally grown to maximize the percentage of large roots, which have USDA grade standards of U.S. fancy, U.S. no. 1, U.S. no. 2 , and unclassified (USDA, 1997). U.S. fancy roots are described as well-trimmed, wellshaped, fairly smooth having good head formation, and a minimum length of 8 inches and $\geq 1.25$ inches diameter. If the length is $>8$ inches, the diameter can be reduced 0.06 inch for each additional 0.5 inch length increase; but no root can have a diameter $<1.25$ inch. U.S. no. 1 roots must have a minimum length of 6 inches with the diameter $\geq 1.25$ inch. If the length is greater than 6 inches, the diameter may be reduced by 0.06 inch for each additional length increase of 0.5 inch, but no root can have a diameter $<\mathrm{l}$ inch. Furthermore, U.S. no. 1 roots can have less shape, smoothness, and head formation compared with U.S. fancy. However,

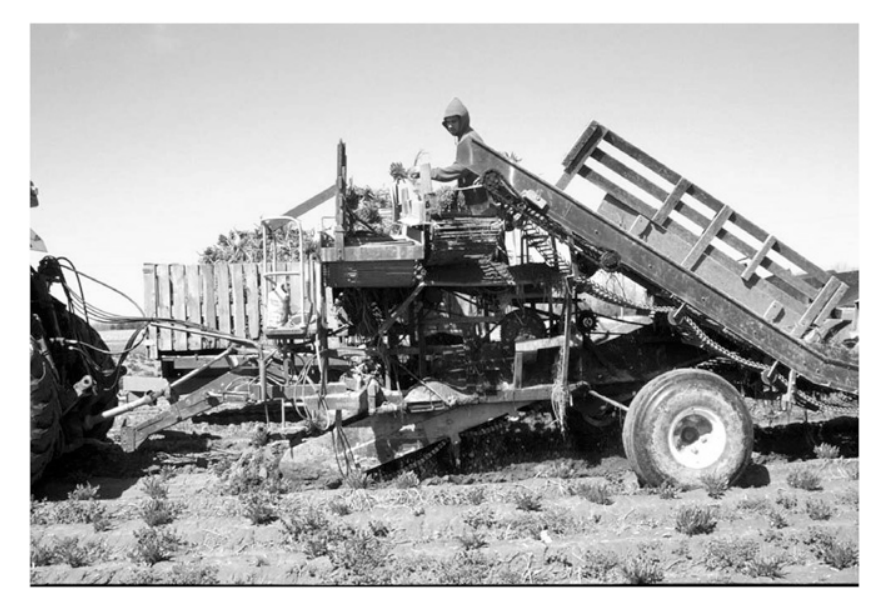

Fig. 7. Horseradish harvest in late autumn using a two-row modified potato digger. 
both of these grades must have no decay, cracks, fracturing, hollowness, internal discoloration, mold, insect, or other significant damage. The U.S. no. 2 grade is similar to U.S. no. 1 , although roots can be smaller with minimum lengths of 4 inches and 0.5 -inch diameter. The unclassified grade includes roots that have not been classified in accordance with any of the U.S. grades. It is not a grade, but is provided as a designation to show that no grade has been applied to the roots. The unclassified grade would include wild root, which indicates that the entire root is marketed, while "trimmings" are the secondary roots that have been cut off the primary roots.

The various root grades are normally packed and marketed separately to obtain the highest price possible. The higher grade roots are packed differently from the wild root or trimmings, using 50- or 100-lb burlap sacks lined with heavy plastic. For wild root or trimmings, the entire bundled root mass is marketed by weight. Roots of different grades can be formed into 500- to 1200-lb cubes and shrink-wrapped with plastic and shipped on wooden pallets (Fig. 8 ). These cubes are placed in cold storage until they are shipped for processing.

Horseradish can be placed in cold storage to prevent rotting and shrinkage for up to 10 to 12 months at 35 to $40{ }^{\circ} \mathrm{F}$ and $>90 \%$ relative humidity (Hardenburg et al., 1986). A high relative humidity is essential to minimize root deterioration during storage. The use of plastic bin liners facilitates the maintenance of high humidity. Roots that are dug when the plant is actively growing do not store as well as those acclimated by cold weather conditions before digging (Hardenburg et al., 1986). Roots should also be stored in darkness, as they can develop greening when exposed to light.

About $80 \%$ of the horseradish produced in Illinois goes directly to the processor for making various condiment products (Swiader et al., 1992). Processors normally work on a contractual basis with growers to purchase various grades in large volumes. Some processors have equipment that can wash and grind any size root, including tangled root masses; however, others only have equipment that can process a large, clean, and trimmed root, therefore growers must go through the process of cleaning, trimming, and separating the various root grades. Generally, relationships between growers and processors have a long history, with the processor used to certain root qualities from specific growers (Bratsch, 2006).

\section{Future of Illinois horseradish industry}

Horseradish is one of the most important specialty crops grown in Illinois, and growers are currently trying to solve specific production issues through research. Although there is no certification program for Illinois horseradish, the University of

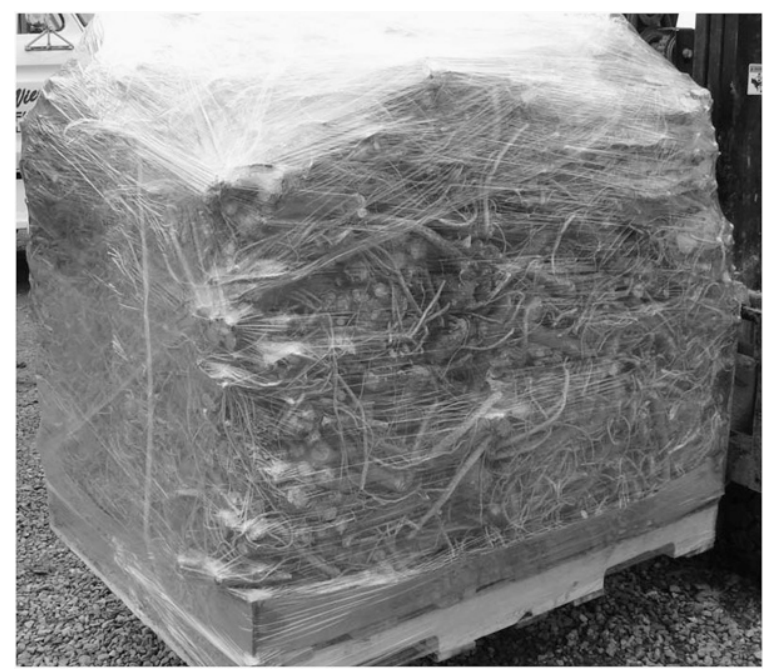

Fig. 8. Wild root grade of horseradish shrink-wrapped and palletized for shipment.

Illinois maintains most of the cultivars and germplasm accessions in tissue culture, which can provide growers with clean planting stock. Internal root discoloration is a concern to the industry, with significant amounts of ongoing research, including breeding for resistance as well as developing better cultural and chemical control options to better manage this disease complex. Thus, a major focus of the horseradish breeding program that is currently housed at Southern Illinois University is the incorporation of IRD resistance into elite materials. Other concerns include obtaining domestic certification that horseradish has been produced in the United States versus foreign importation, continuance of protecting seed stock from free distribution, and maintaining the useable land base due to rapid urbanization from St. Louis into Madison and St. Claire counties of Illinois.

\section{Literature cited}

Atibalentja, N. and D.M. Eastburn. 1998. Verticillum dabliae resistance in horseradish germplasm from the University of Illinois collection. Plant Dis. 82:176180.

Babadoost, M. 2003. Occurrence of horseradish diseases in Illinois in 2002, p. 30-31. In: E.A. Wahle (ed.). Horseradish research review. Proc. Horseradish Growers School, 29-30 Jan. 2003. Univ. Illinois Ext., Edwardsville.

Babadoost, M. and S.Z. Islam. 2004. Fungicide and biocontrol agents for control of internal discoloration of horseradish roots, p. 18-22. In: E.A. Wahle (ed.). Horseradish research review. Proc. Horseradish Growers School, 29 Jan. 2004. Univ. Illinois Ext., Edwardsville.

Babadoost, M., C.L. Wright, W. Chen, and A.D. Bratsch. 2001. A surveillance of horseradish diseases in Illinois in 2000, p. 8-13. In: A.D. Bratsch (ed.). Horseradish research review. Proc. Horseradish Growers School, 25 Jan. 2001. Univ. Illinois Ext., Edwardsville.

Babadoost, M., W. Chen, A.D. Bratsch, and C.E. Eastman. 2004. Verticillium longisporum and Fusarium solani: Two new species in the complex of internal discoloration of horseradish roots. Plant Pathol. 53:669-676.

Babadoost, M., A. Eranthodi, A. Jurgens, K. Hippard, and E.A. Wahle. 2007. Thermo-therapy and use of biofungicides and fungicides for management of internal 
discoloration of horseradish roots: 2006, p. 25-31. In: E.A. Wahle (ed.). Horseradish research review. Proc. Horseradish Growers School, 25 Jan. 2007. Univ. Illinois Ext., Edwardsville.

Berrie, A.M.M. 1977. An introduction to the botany of the major crop plants. Heyden., London.

Boerboom, C.M., L.G. Bundy, A.J. Bussan, J.B. Colquhoun, E.M. Cullen, K.A. Delahaut, R.L. Groves, C.A.M. Laboski, D.L. Mahr, and W.R. Stevenson. 2007. Commercial vegetable production in Wisconsin. Univ. Wisconsin Ext. Publ. A3422.

Bratsch, A.D. 2006. Specialty crop profile: Horseradish. Virginia Coop. Ext. Publ. 438-104.

Burke, M.C. and H.J. Hopen. 1983. Effectiveness of selected herbicides and discing on volunteer horseradish control. J. Amer. Soc. Hort. Sci. 108:145-148.

Chang, R.J. and D.M. Eastburn. 1994. Host range of Verticillium dabliae from horseradish and pathogenicity of strains. Plant Dis. 78:503-506.

Courter, J.W. and A.M. Rhodes. 1969. Historical notes on horseradish. Econ. Bot. 23:156-164.

De Candolle, A. 1959. Origin of cultivated plants (reprint of 2 nd ed., 1886). Hafner, New York.

Doll, C.C., J.W. Courter, J.S. Vandemark, and C.E. Voigt. 1999. Illinois horseradish: A natural condiment. Univ. Illinois Ext. Pamphlet C1084.

Dorris, F., S.A. Walters, and E.A. Wahle. 2007. Horseradish variety survey: 2006, p. 11-13. In: E.A. Wahle (ed.). Horseradish research review. Proc. Horseradish Growers School, 25 Jan. 2007. Univ. Illinois Ext., Edwardsville.

Dorris, F., S.A. Walters, and E.A. Wahle. 2008. Horseradish variety survey: 2007, p. 18-21. In: E.A. Wahle (ed.). Horseradish research review. Proc. Horseradish Growers School, 31 Jan. 2008. Univ. Illinois Ext., Edwardsville.

Eastburn, D. and R. Weinzierl. 1995. Horseradish: A guide to major insect and disease problems (scouting horseradish for IPM). Univ. Illinois Vista Publ., RPD No. 944, 18 Aug. 2009. <http:// web.aces.uiuc.edu/vista/pdf_pubs/944. PDF $>$.

Eastburn, D.M. and R.J. Chang. 1994. Verticillium dabliae: A causal agent of root discoloration of horseradish in Illinois. Plant Dis. 78:496-498.

Fletcher, J., G.A. Schultz, R.E. Davis, C.E. Eastman, and R.M. Goodman. 1981. Brittle root disease of horseradish: Evidence for an etiological role of Spiroplasma citri. Phytopathology 71:1073-1080.

Gerber, J.M. and J.M. Swiader. 1985. Fertilizer guide for commercial vegetable growers. Univ. Illinois Coop. Ext. Serv. Circ. 1185.

Górecka, K. and P. Lehmann. 2001. Infectious diseases of horseradish (Cochlearia armoracia L.) in Poland. Plant Breeding Seed Sci. 45:55-64.

Hardenburg, R.E., A.E. Watada, and C.Y. Wang. 1986. The commercial storage of fruits, vegetables, and florist and nursery stocks. USDA Hdbk. No. 66, U.S. Dept. Agr., Washington, DC.

Horwitz, D.K., J. Fletcher, C. D'Arcy, and A.M. Rhodes. 1985. Turnip mosaic virus in the Illinois horseradish germplasm collection. Plant Dis. 69:246-248.

Johanning, N.R., S.A. Walters, and B.G. Young. 2008a. Illinois volunteer horseradish survey: 2007,p. 13-17. In: E.A. Wahle (ed.). Horseradish research review. Proc. Horseradish Growers School, 31 Jan. 2008. Univ. Illinois Ext., Edwardsville.

Johanning, N.R., S.A. Walters, and B.G. Young. 2008b. Research update on volunteer horseradish control, p. 11-12. In: E.A. Wahle (ed.). Horseradish research review. Proc. Horseradish Growers School, 31 Jan. 2008. Univ. Illinois Ext., Edwardsville.

Khan, A., N. Atibalentja, and D.M. Eastburn. 2000. Influence of inoculum density of Verticillum dabliae on root discoloration of horseradish. Plant Dis. 84:309-315.

Kindhart, J., B. Aly, and C. Doll. 2003. Compost/methyl bromide studies with black plastic mulch in 2001 horseradish plantings, p. 39-40. In: E.A. Wahle (ed.). Horseradish research review. Proc. Horseradish Growers School, 29-30 Jan. 2003. Univ. Illinois Ext., Edwardsville.

Kumar, A. 2003. Software takes the sting out of horseradish production. Food Eng. 75(4):78.

Li, X. and M.M. Kushad. 2004. Correlation of glucosinolate content to myrosinase activity in horseradish (Armoracia rusticana). J. Agr. Food Chem. 52:69506955.

Magee, D.W. and H.E. Ahles. 1999. Flora of the northeast: A manual of the vascular flora of New England and adjacent New York. University of Massachusetts Press, Amherst. MA.

Mano, Y. and M. Matsuhashi. 1995. A novel life cycle arising from leaf segments in plants regenerated from horseradish hairy roots. Plant Cell Rpt. 14:370-374.
Mohlenbrock, R.H. 1975. Vascular flora of Illinois. Southern Illinois University Press, Carbondale, IL.

Mueller, J.P., J.A. Percich, and J.E. Mitchell. 1982. Root deterioration associated with verticillium wilt of horseradish. Plant Dis. 66:410-414.

Olsen, M.W. and D.J. Young. 1998. Plant disease management of horticultural crops: Verticillium wilt. Univ. Arizona Coop. Ext. Publ. AZ1034.

Oregon State University. 2002. Commercial vegetable production series, horseradish (Armoracia rusticana). 20 Jan. 2009. <http://hort-devel-nwrec.hort.oregonstate. edu/horserad.html>.

Raju, B.C., G. Nyland, E.A. Backus, and D.L. McLean. 1981. Association of a spiroplasma with brittle root of horseradish. Phytopathology 71:10671072.

Rhodes, A.M. 1977. Horseradish-problems and research in Illinois, p. 137-146. In: D.S. Siegler (ed.). Crop resources. Academic Press, New York.

Rhodes, A.M., J.W. Courter, and M.C. Shurtleff. 1965a. The identification of horseradish types. Illinois State Acad. Sci. 58:115-122.

Rhodes, A.M., J.W. Courter, M.C. Shurtleff, and J.S. Vandemark. 1965b. Improving horseradish through breeding. Ill. Res. 7(4):17.

Rubatzky, V.E. and M. Yamaguchi. 1997. World vegetables, 2nd ed. Chapman \& Hall, New York.

Rundle, M.F., S.A. Walters, and B.G. Young. 2007. Efficacy of corn and soybean herbicides on volunteer horseradish (Armoracia rusticana). Weed Technol. 21:501-505.

Shehata, A., R.M.S. Mulwa, M. Babadoost, M. Uchanski, M.A. Norton, R. Skirvin, and S.A. Walters. 2009. Horseradish: Botany, horticulture, breeding. Hort. Rev. (Amer. Soc. Hort. Sci.) 35:221-261.

Simon, J.E., A.F. Chadwick, and L.E. Craker. 1984. Herbs: An indexed bibliography 1971-1980, the scientific literature on selected herbs, and aromatic and medicinal plants of the temperate zone. Archon Books, Hamden, CT.

Swiader, J.M., G.W. Ware, and J.P. McCollum. 1992. Producing vegetable crops, 4th ed. Interstate Publishers, Danville, IL.

Uchanski, M., R.M. Skirvin, and M.A. Norton. 2004. The use of in vitro thermotherapy to obtain turnip mosaic virus-free horseradish plants. Acta Hort. 631: 175-179. 


\section{Reviews}

U.S. Department of Agriculture. 1968. Commercial growing of horseradish. USDA Lflt. No. 547.

U.S. Department of Agriculture. 1997. U.S. standards for grades for horseradish roots. 5 Sept. 2009. <http://www.ams. usda.gov/AMSv1.0/getfile?dDocName= STELPRDC5050272>.

U.S. Department of Agriculture. 2000. Crop profile for horseradish in Illinois.
5 Sept. 2009. <http://www.ipmcenters. org/CropProfiles/docs/ILhorseradish. pdf $>$.

Wahle, E.A. and J.B. Masiunas. 2004. The evaluation of preemergent and postemergent herbicides for horseradish, p. 23-27. In: E.A. Wahle (ed.). Horseradish research review. Proc. Horseradish Growers School, 29 Jan. 2004. Univ. Illinois Ext., Edwardsville.
Walters, S.A. 2009. Horseradish pest survey: 2008, p. 43-44. In: E.A. Wahle (ed.). Horseradish research review. Proc. Horseradish Growers School, 29 Jan. 2009. Univ. Illinois Ext., Edwardsville.

Weaver, J.E. and W. Bruner. 1927. Root development of vegetable crops. McGrawHill, New York. 